DOI: 10.2478/ausae-2021-0001

\title{
Effects of two bacterial inoculants and biostimulants on the growth performance of Amaranthus cruentus at different levels of spent-engine-oil-contaminated soil
}

\author{
Adeniyi Olarewaju ADELEYE, ${ }^{* 1,2}$ Mohammed Bello YERIMA, ${ }^{2}$ \\ Michael Edet NKEREUWEM, ${ }^{3}$ Victor Odiamehi ONOKEBHAGBE, ${ }^{3}$ \\ Ismaila Shina SADIQ, ${ }^{4}$ Florence Kemi AMOO, ${ }^{2}$ Madinat RAJI ${ }^{2}$ \\ ${ }^{* 1}$ Department of Environmental Sciences, Federal University Dutse, Nigeria \\ e-mail: adeniyi.adeleye@fud.edu.ng; adeniyiadeleye80@gmail.com \\ ${ }^{2}$ Department of Microbiology and Biotechnology, Federal University Dutse, Nigeria \\ e-mail: belyerima@gmail.com; amooflorence@gmail.com; madinat_raji@yahoo.com \\ ${ }^{3}$ Department of Soil Science, Federal University Dutse, Nigeria \\ e-mail: michael.n@fud.edu.ng; victor.o@fud.edu.ng \\ ${ }^{4}$ Department of Chemistry, Federal University Dutse, Nigeria \\ e-mail: shinasharon@yahoo.co.uk
}

Manuscript received 25 December 2020;

revised 22 January 2021; accepted 30 March 2021

\begin{abstract}
This study was conducted to assess the growth performance of Amaranthus cruentus on spent-engine-oil- (SEO) contaminated soil bioremediated with bacterial inoculants and processed biostimulants: compost, sole cocoa pod husk (CPH), and sole cow dung (CD). SEO with $5 \%, 10 \%$, and $15 \%$ densities was artificially contaminated with sterilized soil. Subsequently, biostimulants and bacterial inoculants, Staphylococcus aureus and Bacillus cereus, were applied. The treatments were replicated three times, adopting a completely randomized design. After the biodegradation assay that lasted for 70 days, Amaranthus cruentus seeds were sown, while its growth parameters, plant height, number of leaves, and stem girth were monitored for 6 weeks after sowing (WAS). The results generated indicate that the applied biostimulants and bacterial inoculants accomplished significant $(\mathrm{P}<0.05)$ reclamation of the SEO-contaminated soil as the test plant recorded substantial growth compared with the controls that recorded no growth. At 2 WAS, compost influenced the highest plant heights $(6.5,7.4$, and $7.5 \mathrm{~cm})$ compared with other biostimulants at 5\%,10\%, and 15\% SEO contamination levels respectively. At 4 WAS, all biostimulants produced the same number of leaves (5.0) at 5\% SEO contamination level, the compost recorded the highest
\end{abstract}


number of leaves (6.0) at 10\% SEO contamination level, while all biostimulants produced the same number of leaves (4.0) at 15\% SEO contamination level. The study showed that the combination of biostimulants and bacterial inoculants significantly reclaimed SEO contaminated soil. Therefore, reclamation of petroleum-impacted environments with the combination of biostimulation and bioaugmentation is recommended.

Keywords: Amaranthus cruentus, bacterial inoculants, biostimulants, spent engine oil, contaminated soil

\section{Introduction}

Amaranthus cruentus is a common leafy vegetable cultivated in all regions in Nigeria and in other West African countries [1]. This vegetable has a fast growth rate, and it is planted all year round, with irrigation in areas with minimal rainfall. There is a high demand for this crop, especially in urban areas, where no primary cultivation of the crop takes place [2]. This has led to making this vegetable an important commodity in our market and to generating an important economic activity for rural women [3]. This vegetable is highly nutritional because of its high content of essential micronutrients such as iron, manganese, and zinc [4]. According to [3], the protein found in the young plants of amaranths can be essential for people who have no access to animal sources of protein.

In Nigeria, the indiscriminate disposal of spent engine oil (SEO) is a rampant practice which invariably leads to the pollution of agricultural land, thereby rendering such land unsuitable for the cultivation of crops [5]. It has been reported by [6] that considerable quantities of petroleum hydrocarbons have the capability of sterilizing the soil, thereby stopping crop growth and yield for a long period of time. According to [7], antagonistic impacts of SEO ranging from reduced germination of seeds, reduced yield, and increased uptake of toxic components of SEO have been detected on plants grown in SEO-polluted soils.

Bioremediation technology is a technique used to restore an environment previously impacted by hydrocarbon contamination. [8] and [9] have reported the cost-effectiveness and eco-friendly nature of bioremediation technology in the treatment of petroleum hydrocarbon and other hydrocarbon-related environmental pollution. [10] reported on the biostimulatory effect of organic fertilizer on hydrocarbon-polluted soil in the lowland forest ecosystem in the Niger Delta region of Nigeria. The authors reported that the enhanced natural attenuation process adopted in their study yielded a significant reduction and an acceptable threshold in the total petroleum hydrocarbon (TPH) values with improved nutrient concentrations and bioavailability recorded at the end of the experiment when compared with the high TPH values measured at the start of the experiment. This study was, however, conducted with a view to assessing the growth performance 
of Amaranthus cruentus on SEO-contaminated soil biostimulated with compost made of cocoa pod husk (CPH) and cow dung (CD), sole CPH, sole cow dung (CD), and bioaugmented with Staphylococcus aureus and Bacillus cereus co-culture.

\section{Materials and methods}

\section{Experimental site}

This research was conducted at the Teaching and Research Farm of the Federal University Dutse, Jigawa State, Nigeria. According to [11], Dutse is located at latitude 11046 '39" $\mathrm{N}$ and longitude $9020^{\prime} 3$ ”' $\mathrm{E}$. The area is known for its undulating relief, which is principally categorized as Sudanese savannah agro-ecological zone [12].

\section{Collection and processing of biostimulants}

The three (3) bio-enhancement formulations, compost (generated from the composting of $\mathrm{CPH}$ and $\mathrm{CD}$ ), sole $\mathrm{CPH}$, and sole $\mathrm{CD}$, employed for biostimulation in this study were collected and subsequently processed according to the procedures described by [13] and [14].

\section{Collection and processing of soil}

As done by [15], $250 \mathrm{~kg}$ top soil (0-25 $\mathrm{cm}$ depth) that had not had any history of pollution was collected from four different points in the area situated behind the Department of Soil Science, Federal University Dutse main campus. The soil was air-dried and bulked with a view to producing composite sample.

\section{Collection of spent engine oil}

Twenty (20) litres of SEO was obtained from one of the service pits in Mechanic Village Dutse, Jigawa State.

Isolation and identification of the inoculant bacteria adopted for bioaugmentation

Ten (10) g of soil that had been naturally polluted with SEO was collected at a depth of $5 \mathrm{~cm}$ from the Dutse mechanic village. The bacterial isolate that was adopted as co-culture inoculant in this study was isolated from a SEO-polluted soil by applying the procedure as described in [16], and it was subsequently identified according to the procedures outlined by [17]. 


\section{Determination of the physicochemical properties of the samples}

Soil samples taken from natural soil, SEO-polluted soil, and organic materials employed in this study were subjected to various analyses ranging from $\mathrm{pH}$ values to electrical conductivity (EC) in deionized water (1: $2.5 \mathrm{w} / \mathrm{v}$ for soil, and 1: $5 \mathrm{w} / \mathrm{v}$ for organic materials). Organic carbon was analysed via the modified WalkleyBlack procedure [18], while the cation exchange capacity (CEC) was determined through the summation method described by [19]. Total nitrogen and phosphorous contents of all the samples were estimated through the Kjeldhal and Bray-1 method in reference to [20] and [21]. The soil mechanical analysis was similarly determined by the hydrometer method described by [22].

\section{Preparation and contamination of soil}

As established by [23], the bulked soil was sieved with $2 \mathrm{~mm}$ mesh size. The soil was autoclaved at $121^{\circ} \mathrm{C}$ for 15 minutes so as to expunge the extraneous effect of undesirable microbial life. Subsequently, the sterile soil that had undergone autoclaving weighing $1.5 \mathrm{~kg}$ was put into 108 polyethylene bags and $75 \mathrm{ml}, 150$ $\mathrm{ml}$, and $225 \mathrm{ml}(\mathrm{w} / \mathrm{w})$ SEO levels were added separately, indicating $5 \%, 10 \%$, and $15 \%$ contamination levels respectively. As suggested by [15], the soil and the varying contamination levels with SEO were meticulously mixed together and left undisturbed for 14 days so as to ensure the desirable volatilization of the toxic components of the oil.

\section{Biodegradation experiment}

The biodegradation assay conducted in this study was done according to the procedures described by [14]. This involved a bacterial co-culture, which was bioaugmented with the SEO-contaminated soil in each experimental bag apart from the controls, which did not receive such bioaugmentation and biostimulation. All the 108 polyethylene experimental bags were subsequently incubated at room temperature for 70 days, as outlined by [24].

\section{Experimental layout}

The experiment was set up by adopting a completely randomized design, whereby three (3) replicates were employed for each biostimulant and each SEO contamination level. 


\section{Screen house experiment}

After 70 days of bacterial remediation of SEO from the soil, the sowing of Amaranthus cruentus seeds was done as established by [15]. This was done with a view to assessing the growth performance: plant height (measured in centimetres using a metre rule), stem girth (measured in centimetres using a metre rule), and number of leaves (counted visually) of the test crop on bacterial remediated SEOcontaminated soil. As outlined by [25], five seeds of Amaranthus cruentus were sown directly into the experimental bags. Two weeks after sowing, it was thinned down to one plant per experimental bag. The experiment was terminated at the $6^{\text {th }}$ WAS.

\section{Statistical analysis}

All data collected were subjected to analysis of variance (ANOVA) using GenStat version 17, while Duncan's multiple range test (DMRT) was employed to separate significant means at $5 \%$ level of significance.

\section{Results and discussions}

Physicochemical properties of biostimulants and soils

The determined properties of the biostimulants and soils are presented in Table 1. The sum of exchangeable bases (SEB) of the compost, sole CD, and sole $\mathrm{CPH}$ used in this study recorded $221.7 \mathrm{cmol} \mathrm{kg}^{-1}, 82.1 \mathrm{cmol} \mathrm{kg}^{-1}$, and $166.15 \mathrm{cmol}$ $\mathrm{kg}^{-1}$ respectively, while the SEB of the natural soil devoid of pollution and SEOcontaminated soil employed in this study recorded $3.51 \mathrm{cmol} \mathrm{kg}^{-1}$ and $1.05 \mathrm{cmol}$ $\mathrm{kg}^{-1}$ respectively. The compost, sole CD, and sole CPH recorded $213.16 \mathrm{cmol} \mathrm{kg}$, $80 \mathrm{cmol} \mathrm{kg}^{-1}$, and $162 \mathrm{cmol} \mathrm{kg}^{-1}$ potassium respectively. $\mathrm{pH}$ in water obtained from the soils shows that it was slightly acidic, while $\mathrm{pH}$ obtained from the compost, sole CD, and sole CPH was slightly alkaline to alkaline as shown in Table 1. This alkalinity can be linked to the high levels of exchangeable bases, which are characteristic of organic materials as shown in Table 1.

Table 1. Physicochemical properties of soils and biostimulants

\begin{tabular}{lccccc}
\hline Parameters & $\begin{array}{c}\text { Natural } \\
\text { soil }\end{array}$ & SEOCS & Compost & Sole CD & Sole CPH \\
\hline Moisture content (\%) & 2.04 & 0.8 & 2.0 & 7.3 & 11.11 \\
\hline Ash content (\%) & - & - & 65 & 68.8 & 23 \\
\hline pH (water) & 6.5 & 6.8 & 9.45 & 8.15 & 7.6 \\
\hline
\end{tabular}




\begin{tabular}{lccccc}
\hline Parameters & $\begin{array}{c}\text { Natural } \\
\text { soil }\end{array}$ & SEOCS & Compost & Sole CD & Sole CPH \\
\hline Organic carbon (\%) & 0.49 & 0.52 & 48.25 & 41.55 & 33.40 \\
\hline Total nitrogen (\%) & 0.06 & 0.08 & 5.85 & 2.85 & 2.65 \\
\hline $\begin{array}{l}\text { Available phosphorous } \\
\text { (mg kg-1) }\end{array}$ & 11.02 & 9.40 & 1.48 & 1.2 & 0.08 \\
\hline EC (dS cm-1) & 0.92 & 1.20 & 8.86 & 8.10 & 6.42 \\
\hline $\begin{array}{l}\text { Exchangeable bases } \\
\text { (cmol kg-1) }\end{array}$ & & & & & \\
\hline Potassium & 0.19 & 0.07 & 213.16 & 80 & 162 \\
\hline Calcium & 1.82 & 0.63 & 4.8 & 0.2 & 1.6 \\
\hline Magnesium & 0.92 & 0.18 & 3.24 & 1.5 & 2.45 \\
\hline Sodium & 0.58 & 0.17 & 0.5 & 0.4 & 0.1 \\
\hline SEB & 3.51 & 1.05 & 221.7 & 82.1 & 166.15 \\
\hline Particle size (g kg-1) & & & & & \\
\hline Clay + Silt & 420 & 200 & - & - & - \\
\hline Clay & 100 & 120 & - & - & - \\
\hline Silt & 320 & 80 & - & - & - \\
\hline Sand & 580 & 800 & - & - & - \\
\hline Textural class & Sandy & Loamy & - & & - \\
\hline & Loam & Sand & & & \\
\hline
\end{tabular}

Note: - = Nil; SEOCS= Spent-engine-oil-contaminated soil; SEB= Sum of exchangeable bases.

\section{Effects of biostimulants on the growth of Amaranthus cruentus on spent-engine-oil-bioremediated soil}

Results recorded with regard to the effect of the biostimulants on the plant height of Amaranthus cruentus were significant $(\mathrm{P}<0.05)$ at 2 WAS, 4 WAS, and 6 WAS. Compost influenced the highest plant heights $(6.5,7.4$, and $7.5 \mathrm{~cm})$ compared with other biostimulants at 5\%, 10\%, and 15\% SEO contamination levels respectively (Table 2). At 4 WAS, the compost further recorded a significant increment in plant heights (10.8 and $11.2 \mathrm{~cm}$ ) at 5\% and 15\% SEO contamination levels respectively, while sole $\mathrm{CPH}$ produced the highest plant height $(18.3 \mathrm{~cm})$ at $10 \%$ SEO contamination levels compared with other biostimulants (Table 3). Compared with other biostimulants at 5\% and 15\% SEO contamination levels, the compost produced the highest plant heights (28.3 and $28.2 \mathrm{~cm}$ respectively) at 6 WAS, while sole CPH recorded the highest plant height $(30.5 \mathrm{~cm})$ at $10 \% \mathrm{SEO}$ contamination level compared with other biostimulants (Table 4). 
Table 2. Growth of test crop on bioremediated spent-engine-oil-contaminated soil at 2 WAS

\section{SEO-contaminated levels}

\begin{tabular}{lccccccccc}
\hline & $5 \%$ & $10 \%$ & $15 \%$ & $5 \%$ & $10 \%$ & $15 \%$ & $5 \%$ & $10 \%$ & $15 \%$ \\
\hline Biostimulants & \multicolumn{2}{c}{ Plant height $(\mathrm{cm})$} & \multicolumn{2}{c}{ Number of leaves } & \multicolumn{2}{c}{ Stem girth $(\mathrm{cm})$} \\
\hline Compost & $6.5^{\mathrm{c}}$ & $7.4^{\mathrm{a}}$ & $7.5^{\mathrm{a}}$ & $3.7^{\mathrm{a}}$ & $4.0^{\mathrm{a}}$ & $3.7^{\mathrm{a}}$ & $0.6^{\mathrm{d}}$ & $0.8^{\mathrm{c}}$ & $0.5^{\mathrm{e}}$ \\
\hline CPH only & $6.4^{\mathrm{c}}$ & $7.2^{\mathrm{b}}$ & $5.9^{\mathrm{d}}$ & $4.0^{\mathrm{a}}$ & $3.7^{\mathrm{a}}$ & $3.7^{\mathrm{a}}$ & $0.9^{\mathrm{b}}$ & $1.2^{\mathrm{a}}$ & $0.5^{\mathrm{e}}$ \\
\hline CD only & $5.4^{\mathrm{e}}$ & $6.0^{\mathrm{d}}$ & $4.1^{\mathrm{f}}$ & $4.0^{\mathrm{a}}$ & $4.0^{\mathrm{a}}$ & $3.3^{\mathrm{a}}$ & $0.8^{\mathrm{c}}$ & $0.6^{\mathrm{d}}$ & $0.3^{\mathrm{f}}$ \\
\hline Control & $0.0^{\mathrm{g}}$ & $0.0^{\mathrm{g}}$ & $0.0^{\mathrm{g}}$ & $0.0^{\mathrm{b}}$ & $0.0^{\mathrm{b}}$ & $0.0^{\mathrm{b}}$ & $0.0^{\mathrm{i}}$ & $0.0^{\mathrm{i}}$ & $0.0^{\mathrm{i}}$ \\
\hline
\end{tabular}

Note: Means with the same letters in each column are not significantly different using Duncan's multiple range test (DMRT); (P > 0.05).

Table 3. Growth of test crop on bioremediated spent-engine-oil-contaminated soil at 4 WAS

\begin{tabular}{lccccccccc}
\hline \multicolumn{7}{c}{ SEO-contaminated levels } \\
\hline & $5 \%$ & $10 \%$ & $15 \%$ & $5 \%$ & $10 \%$ & $15 \%$ & $5 \%$ & $10 \%$ & $15 \%$ \\
\hline Biostimulants & \multicolumn{7}{c}{ Plant height $(\mathrm{cm})$} & \multicolumn{7}{c}{ Number of leaves } & \multicolumn{2}{c}{ Stem girth $(\mathrm{cm})$} \\
\hline Compost & $10.8^{\mathrm{g}}$ & $17.8^{\mathrm{b}}$ & $11.2^{\mathrm{e}}$ & $4.7^{\mathrm{b}}$ & $5.0^{\mathrm{ab}}$ & $4.3^{\mathrm{b}}$ & $1.4^{\mathrm{c}}$ & $1.5^{\mathrm{b}}$ & $1.4^{\mathrm{c}}$ \\
\hline CPH only & $15.4^{\mathrm{c}}$ & $18.3^{\mathrm{a}}$ & $11.0^{\mathrm{f}}$ & $4.3^{\mathrm{b}}$ & $5.7^{\mathrm{a}}$ & $4.3^{\mathrm{b}}$ & $1.2^{\mathrm{e}}$ & $2.4^{\mathrm{a}}$ & $1.2^{\mathrm{e}}$ \\
\hline CD only & $12.5^{\mathrm{d}}$ & $8.3^{\mathrm{h}}$ & $6.8^{\mathrm{i}}$ & $5.0^{\mathrm{ab}}$ & $4.3^{\mathrm{b}}$ & $4.3^{\mathrm{b}}$ & $1.3^{\mathrm{d}}$ & $1.2^{\mathrm{e}}$ & $0.8^{\mathrm{d}}$ \\
\hline Control & $0.0^{\mathrm{j}}$ & $0.0^{\mathrm{j}}$ & $0.0^{\mathrm{j}}$ & $0.0^{\mathrm{c}}$ & $0.0^{\mathrm{c}}$ & $0.0^{\mathrm{c}}$ & $0.0^{\mathrm{f}}$ & $0.0^{\mathrm{f}}$ & $0.0^{\mathrm{f}}$ \\
\hline
\end{tabular}

Note: Means with the same letters in each column are not significantly different using Duncan's multiple range test (DMRT); (P > 0.05).

Table 4. Growth of test crop on bioremediated spent-engine-oil-contaminated soil at 6 WAS

\begin{tabular}{lccccccccc}
\hline & \multicolumn{7}{c}{ SEO-contaminated levels } \\
\hline & $5 \%$ & $10 \%$ & $15 \%$ & $5 \%$ & $10 \%$ & $15 \%$ & $5 \%$ & $10 \%$ & $15 \%$ \\
\hline Biostimulants & \multicolumn{1}{c}{ Plant height $(\mathrm{cm})$} & \multicolumn{1}{c}{ Number of leaves } & \multicolumn{2}{c}{ Stem girth $(\mathrm{cm})$} \\
\hline Compost & $28.3^{\mathrm{c}}$ & $28.6^{\mathrm{b}}$ & $28.2^{\mathrm{d}}$ & $8.0^{\mathrm{c}}$ & $9.0^{\mathrm{b}}$ & $8.0^{\text {cd }}$ & $2.6^{\mathrm{c}}$ & $2.7^{\mathrm{b}}$ & $2.5^{\mathrm{d}}$ \\
\hline CPH only & $23.0^{\mathrm{f}}$ & $30.5^{\mathrm{a}}$ & $23.3^{\mathrm{e}}$ & $8.0^{\text {cd }}$ & $10.0^{\mathrm{a}}$ & $7.0^{\mathrm{e}}$ & $2.3^{\mathrm{f}}$ & $2.8^{\mathrm{a}}$ & $2.6^{\mathrm{c}}$ \\
\hline CD only & $21.6^{\mathrm{g}}$ & $20.8^{\mathrm{h}}$ & $20.3^{\mathrm{i}}$ & $8.0^{\mathrm{cd}}$ & $7.0^{\mathrm{e}}$ & $7.0^{\mathrm{ce}}$ & $2.5^{\mathrm{d}}$ & $2.4^{\mathrm{e}}$ & $2.4^{\mathrm{e}}$ \\
\hline Control & $0.0^{\mathrm{j}}$ & $0.0^{\mathrm{j}}$ & $0.0^{\mathrm{j}}$ & $0.0^{\mathrm{f}}$ & $0.0^{\mathrm{f}}$ & $0.0^{\mathrm{f}}$ & $0.0^{\mathrm{g}}$ & $0.0^{\mathrm{g}}$ & $0.0^{\mathrm{g}}$ \\
\hline
\end{tabular}

Note: Means with the same letters in each column are not significantly different using Duncan's multiple range test (DMRT); $(\mathrm{P}>0.05)$. 
All the biostimulants significantly enhanced the number of leaves of Amaranthus cruentus on all the SEO contamination levels employed in this study $(\mathrm{P}<0.05)$. At 2 WAS, both sole CPH and sole CD produced the highest number of leaves (4.0), compost and sole CD produced the highest number of leaves (4.0), while compost and sole $\mathrm{CPH}$ recorded the highest number of leaves (3.7) at $5 \%, 10 \%$, and $15 \%$ SEO contamination levels respectively (Table 2). At 4 WAS, sole CD produced the highest (5.0) number of leaves, sole CPH produced the highest number of leaves (5.7), while all the biostimulants recorded the same number of leaves (4.3) at 15\% SEO contamination level (Table 3). At 6 WAS, all the biostimulants produced the same number of leaves (8.0), sole CPH produced the highest (10.0) number of leaves, and the compost produced the highest (8.0) number of leaves at $5 \%$, $10 \%$, and $15 \%$ SEO contamination levels respectively (Table 4). In this study, the number of leaves significantly decreased in the test crop cultivated on SEO soil, and it can be clearly seen that these decreases were followed by successive increases in SEO intensity. This finding is in line with the report of [26], where a decrease in the number of the leaves of amaranth crop grown in SEO-contaminated soil was documented.

The stem girths of all Amaranthus cruentus sown and measured in this study were significantly enhanced by all biostimulants employed $(\mathrm{P}<0.05)$. Explicitly, at 2 WAS, compared with other organic amendments employed, sole CPH produced the best stem girths $(0.9$ and $1.2 \mathrm{~cm})$ at $5 \%$ and $10 \%$ SEO contamination levels respectively, while both compost and sole $\mathrm{CPH}$ produced statistically similar stem girth $(0.5 \mathrm{~cm})$ at $15 \%$ SEO contamination level (Table 2). Compared with other organic amendments utilized in this study, the compost produced the best stem girth $(1.4 \mathrm{~cm})$ on both $5 \%$ and $15 \%$ SEO contamination levels, while sole CPH produced the best stem girth $(2.4 \mathrm{~cm})$ at $10 \%$ SEO contamination level at 4 WAS (Table 3). At 6 WAS, compared with other amendments, compost produced the best stem girth $(2.6 \mathrm{~cm})$ at $5 \% \mathrm{SEO}$ contamination level, while sole $\mathrm{CPH}$ only produced the better stem girths $(2.8$ and $2.6 \mathrm{~cm})$ at $10 \%$ and $15 \%$ SEO contamination levels respectively (Table 4).

Generally, the growth performance of Amaranthus cruentus planted on the SEO-bioremediated soil in this study was poor. The results are in agreement with the report of [27] on the poor performance of horticultural crops planted in crude-oil-polluted farms compared to those planted in unpolluted farms. In this study, Amaranthus cruentus seeds sown on all the experimental pots used as control did not germinate at all. The inability of the seeds to germinate can be ascribed to their sensitivity to the residual effect of the SEO content still obtainable in the soil after the termination of the biodegradation experiment. This finding corroborates the report of [6] on the ability of petroleum hydrocarbons to institute soil sterility, thereby preventing seed germination, crop growth, and yield. Similar to the findings in this study, [28] have reported that the presence of petroleum 
hydrocarbons adversely affects the germination and growth of plants in soils. It has been reported by [29] that petroleum hydrocarbons affect the growth of plants by creating conditions which enable vital nutrients in the form nitrogen and oxygen required for plant growth unobtainable for utilization.

The significant growth of Amaranthus cruentus observed with the bioremediated SEO-contaminated soil in this study is not unconnected with the bioremediating synergy attained by the bioenhancement formulations adopted. The significant results obtained on all measured agronomic parameters are in agreement with [15], who reported the ability of organic amendments in the reduction of adverse effects accruable from the presence of hydrocarbon-related pollution. A similar submission on the ability of organic amendments to enhance the growth parameters of Amaranthus cruentus significantly has been reported by [3].

As shown in this study, a similar observation made by [30] showed that the germination of seeds and the growth parameters of plants can be negatively affected by the deleterious effects of hydrocarbons. The significant growth parameters of Amaranthus cruentus recorded in this study could be credited to the supplementation of the SEO-contaminated soil with organic nutrients that aided significant bacterial reclamation of the contaminated soil. A similar submission was made by [31] on the ability of biostimulation and bioaugmentation to restore hydrocarbon-polluted soil, thereby attaining significant improvement in the growth of the test crops employed in their respective studies.

\section{Conclusions}

The study revealed that SEO was significantly removed from the SEO-contaminated soil that was subjected to bioremediation technology compared to the control. The results obtained in the screen house experiment performed to evaluate the growth parameters, plant heights, number of leaves, and stem girths of Amaranthus cruentus, with a view to assessing a possible bacterial reclamation of the SEO-contaminated soil that had undergone bioremediation for 70 days, show that a significant performance was recorded compared with the experimental bags adopted as control, which recorded no germination of the sown Amaranthus cruentus seeds.

\section{Recommendation}

Based on the results obtained in this study, the combination of bioaugmentation and biostimulation methods adopted for the reclamation of SEO-contaminated soil employed is hereby recommended for the clean-up of hydrocarbon-impacted environments. 


\section{References}

[1] Saunder, R. A., Beciker, R. (1984), Amaranthus: A potential food and feed resource. In: Advanced Science Technology. Cereal Chemist. St Paul, MN.

[2] Schippers, R. R. (2000), African indigenous vegetables. An overview of the cultivated species. Natural Resources Institute/ACP-EU Technical Centre for Agricultural and Rural Cooperation, Chatham, UK.

[3] Law-Ogbomo, K. E., Ajayi, S. O. (2009), Growth and yield performance of Amaranthus cruentus influenced by planting density and poultry manure application. Notulae Botanicae Horti Agrobotanici Cluj-Napoca 37(1), 195199.

[4] Mnkeni, A. P., Masika, P. Maphaha, M. (2007), Nutritional quality of vegetable and seed from different accessions of Amaranthus in South Africa. Water SA 33(3), 377-380.

[5] Anoliefo, G. O., Vwioko, D. E. (2001), Tolerance of Chromolaena odorata (L) K. and R. grown in soil contamination with spent lubrication oil. Journal of Tropical Biosciences 1, 20-24.

[6] Onwurah, I. N. E., Ogugua, V. N., Onyike, N. B., Ochonogor, A. E., Otitoju, O. F. (2007), Crude oil spills in the environment, effects and some innovative clean-up biotechnologies. International Journal of Environmental Research 1(4), 307-320.

[7] Akinola, O., Udo, A. S., Okwok, N. (2004), Effect of crude oil (Bonny Light) on germination, early seedling growth and pigment content in maize (Zea mays L.). Journal of Science, Technology and Environment 4(1-2), 6-9.

[8] Yerima, M. B., Agina, S. E., Zuru, A. A., Venil, K., Farouq, A. A., Maishanu, H. M., Shinkafi, A. L., Kashim, Z. A. (2011), Assessment of biostimulation using some organic wastes in bacterial reclamation of crude oil contaminated agricultural soil. Journal of Sustainable Development and Environmental Protection 1(1), 69-76.

[9] Adeleye, A. O., Yerima, M. B., Nkereuwem, M. E., Onokebhagbe, V. O. (2017), Biostimulatory effects of organic nutrients on spent engine oil and hydrocarbon related soil pollution: A review. International Journal of Applied Research and Technology 6(7), 52-60.

[10] Akpan, E. E., Ogboi, K. C., Nwadinigwe, C. A. (2013), Bioremediation of hydrocarbon polluted soil in the lowland forest ecosystem in the Niger Delta through enhanced natural attenuation process (ENAP). International Journal of Applied Science and Technology 3(8), 128-137.

[11] Raji, M., Amoo, F. K., Adeleye, A. O., Amoo, A. O., Bate, G. B., Farouk, R. U. (2019), Isolation and screening of spent engine oil utilizing bacteria for the production of biosurfactants. FUPRE Journal of Scientific and Industrial Research 3(3), 12-23. 
[12] Britannica (2019), Dutse, Nigeria. Retrieved from: https://www.britannica. com/place/Dutse. Accessed on: 19 June 2019.

[13] Adeleye, A. O., Onokebhagbe, V. O., Nkereuwem, M. E., Omeke, J. O., Yerima, M. B. (2019a), Isolation and identification of bacteria associated with the compost generated from cocoa pod husk and cow dung. FUPRE Journal of Scientific and Industrial Research 3(3), 1-11.

[14] Adeleye, A. O., Yerima, M. B., Nkereuwem, M. E., Onokebhagbe, V. O., Shiaka, P. G., Amoo, F. K., Adam, I. K. (2019b), Effect of organic amendments on the decontamination potential of heavy metals by Staphylococcus aureus and Bacillus cereus in soil contaminated with spent engine oil. Novel Research in Microbiology Journal 3(5), 471-484.

[15] Agbor, R. B., Ekpo, I. A., Kalu, S. E., Bassey, I. U., Okoi, E. P., Ude, E. O. (2015), Growth pattern of two crop species on bio-remediated hydrocarbon polluted soils. Academic Journals 10(2), 58-63.

[16] Adeleye, A. O., Yerima, M. B. (2019), Isolation and identification of spent engine oil utilizing bacteria from Mechanic Village Dutse, Jigawa State. Paper presented at The $42^{\text {nd }}$ Conference of the Nigerian Society for Microbiology. Crawford University, Igbesa, Ogun State.

[17] Barrow, G. I., Feltham, R. K. A. (1993), Cowan and Steel's manual for the identification of medical bacteria. Cambridge University Press, $3^{\text {rd }}$ edition. 52101. Retrieved from: https://www.academia.edu/8106702/Cowan_and_Steels_ manual_for_the_identification_of_medical_bacteria_COWAN_AND_STEELS_ Manual_for_the_identification_of_medical_bacteria_THIRD_EDITION_ EDITED_AND_REVISED_BY. Accessed on: 2 July 2019.

[18] Nelson, D. W., Sommers, L. E. (1996), Total carbon, organic carbon and organic matter. In: Sparks, D. L. (ed.), Methods of soil analysis, part 2. Madison: America Society of Agronomy. 961-1010.

[19] Chapman, H. D. (1965), Cation exchange capacity. In: Black, C. A., Methods of Soil Analysis. Madison: Agronomy Journal. 891-901.

[20] Reeuwijk, V. (1993), Procedures for soil analysis; Technical paper No. 9. Fourth Edition. International Soil Reference and Information Centre (ISRIC).

[21] Bremmer, J. M. (1996), Nitrogen-total. In: Miller, A., Keeny, D., Methods of soil analysis. Madison, USA: American Society of Agronomy. 595-624.

[22] Bouyoucous, G. (1962), Hydrometer method improved for making particle analyses of soils. Agronomy Journal 53, 464-465.

[23] Soretire, A. A., Oshiobugie, A. A., Thanni, B. M., Balogun, S. A., Ewetola, J. M. (2017), Bioremediation of soil contaminated with crude oil using fresh and decomposed animal manure. Nigerian Journal of Biotechnology 34, 12-18.

[24] Chorom, M., Sharifi, H. S., Motamedi, H. (2010), Bioremediation of a crude oil polluted soil by application of fertilizers. Iranian Journal of Environmental Health Science and Engineering 7(4), 319-326. 
[25] Onokebhagbe, O. V., Abdu, N., Santuraki, H. A. (2018), Residual effects of biochar on dry matter yield of grain amaranths (Amaranthus cruentus) grown on Alfisols of Nigerian Northern Guinea and Sudan Savanna agro-ecologies. Dutse Journal of Agriculture and Food Security (DUJAFS) 5(1), 97-108.

[26] Nkereuwem, M. E., Edem, I. D., Fagbola, O. (2010), Bioremediation of oil polluted soils with organo-mineral fertilizer (OMF) and mexican sunflower (Tithonia diversifolia). Nigerian Journal of Agriculture, Food and Environment 6(1-2), 13-30.

[27] Ojimba, T. P., Iyagba, A. G. (2012), Effects of crude oil pollution on horticultural crops in Rivers State, Nigeria. Global Journal of Science Frontier Research Agriculture and Biology 12(4), 37-43.

[28] Agbogidi, O. M., Eruotor, P. G., Akparobi, S. O. (2007), Effects of time of application of crude oil to soil on the growth of maize (Zea mays L.). Research Journal of Environmental Toxicology 1, 116-123.

[29] Adam, G., Duncan, H. J. (2002), Influence of diesel fuel on seed germination. Environmental Pollution 120: 363-370.

[30] Inckot, R. C., Santos, G. D. O., de Souza, L. A., Bona, C. (2011), Germination and development of Mimosa pilulifera in petroleum-contaminated soil and bioremediated soil. Flora - Morphology. Distribution, Functional Ecology of Plants 206, 261-266.

[31] Nwadinigwe, A. O., Onyeidu, E. G. (2012), Bioremediation of crude oil polluted soil using bacteria and poultry manure monitored through soybean productivity. Polish Journal of Environmental Studies 21(1), 171-176. 